\title{
sciendo
}

\author{
RURAL SUSTAINABILITY RESEARCH 46(341), 2021 \\ ISSN - 2256-0939 \\ (c) Latvia University of Life Sciences and Technologies, all rights reserved \\ http://www.llu.Iv/en/

\section{Opportunities for Commercialization of High-Protein Barley: Case of New Variety 'Kornelija'} \\ *Alberts Auziṇš, Ieva Leimane, Māra Bleidere, Vita Šterna, Agnese Krieviṇa \\ Institute of Agricultural Resources and Economics, 14 Struktoru street, Rīga, Latvia
}

\begin{abstract}
The objective of the study was to define the main opportunities and challenges for the commercialization of the new hulless barley variety 'Kornelija' arising from its biochemical and farming profile, and to present the evaluation for the approach to a new high protein-based payment system. Unlike the agricultural profile with both advantages and disadvantages, the variety shows distinctive grain quality and biochemical properties. Although there is a growing demand for high-nutrition and plant-based protein foods, farmers are focused on yield potential, not the nutritional value of cereals. By paying for the grains of 'Kornelija' the price that is equal or higher than winter wheat referenced break-even price, food processors would both motivate farmers to grow the variety and obtain grains with much higher protein content, and significantly higher $\beta$-glucans content than winter wheat to produce functional foods for a price that is close to the price of winter wheat.
\end{abstract}

Keywords: high-protein, barley, 'Kornelija', commercialization, protein price.

\section{Introduction}

There is a growing demand for protein globally caused by rising world population and higher incomes, as well as due to the increasing awareness of the role of protein in a healthy diet, including its contribution to healthy aging (aging population) and weight loss (obesity) (Henchion et al., 2017; $\mathrm{Yu}$ et al., 2019). Furthermore, the transition to a more sustainable food production is also taking place, and the orientation of consumers and industry towards plant-based and high-protein products is expanding (Hoehnel et al., 2019). It is generally accepted that plant-based protein has less negative environmental impact (less greenhouse gas emissions and associated climate change, less use of water resources and land) (Henchion et al., 2017), and its consumption is considered more ethical (animal welfare) and healthier (Janssen et al., 2016; Lin et al., 2017).

Increased demand and potential of plant-based proteins has also been highlighted by the market research in the framework of the smart protein project (European Commission, 2018). Also, according to the market research and analysis company New Nutrition Business, "plant-based" and "protein" were among the 10 key trends in food, nutrition and health for 2020, while four mega trends (must-do for all companies) were "naturally functional", "fragmentation", "snackification" and "sustainability" (Mellentin, 2019).

Currently, the EU is importing about 15.7 million tonnes of protein-rich plants (in crude protein), which is almost the same amount as its production, being highly dependent on the imports of protein-rich plants, particularly soya, majority of which comes from Argentina and Brazil - through a very long delivery chain, mainly GMO and involving environmentally destructive monoculture production practices (Clément et al., 2018; Auzins et al., 2019; Leguizamón, 2014; MartinezRibaya and Areal, 2020). The EU-plant protein plan advocates the production of plant protein crops as raw material for the feed and the food industry, seeking not only to decrease the EU import-dependency, but also contribute to solving of economic and environmental problems in agriculture, including healthier diets of EU inhabitants. Although feed market is by far the largest market for plant proteins, it is the food market for plant proteins that is experiencing doubledigit growth in the EU, at the same time, the development of it is highly dependent on well-functioning supply chains and availability of the appropriate raw material. While food market for plant proteins offers highest profit margins, farmers often have very small volumes and there is a need for establishment of supply chains (European Comission, 2018).

Overall, increasing customer standards regarding animal welfare, environmental impact, type of production - such as non-GMO, organic and local food offer great opportunities for EU-grown plant-based protein rich raw material from agriculture.

The object of this paper is a new hulless barley (Hordeum vulgare L.) variety 'Kornelija', developed in Latvia by the Institute of Agricultural Resources and Economics (AREI). The grain of 'Kornelija' has a unique biochemical composition and a superb dietary value. This variety is capable of 
providing a substantially higher protein compared to other grain species that lists it among protein-rich plants (crude protein content of more than 15\% (European Commission, 2018)). Also, the variety is rich in total fibre, has high $\beta$ glucans (Bleidere \&Grunte, 2015) and phenolic compounds contents and the activity thereof (Bleidere et al., 2013a). Therefore, nutritional properties of the new hulless barley variety 'Kornelija' present great opportunities for the development of functional and dietary niche products that can meet the existing and future consumer trends in the food market. At the same time, yield potential of the variety initially did not offer an instant appeal to the farmers and did not attract their attention. The focus of the modern agriculture on higher yield often means a loss of nutritional value, as grain yield and grain protein concentration tend to be negatively correlated (Rajala et al., 2011; Peltonen-Sainio et al., 2012).

Thus, the problem exists: on the one hand, there is a growing demand from consumers for high-nutrition and plant-based protein foods, meanwhile processers lack appropriate raw materials because farmers are rather interested in yield potential, not the nutritional value of cereals, owing to the supply quantity of raw materials currently being one of the most important factors determining revenues per hectare.

In order to ensure that high nutritional and high protein content hulless barley is introduced into the market of raw materials for food production, the pull from the processors is necessary or even crucial, and the commercialisation process should be implemented to facilitate this.

Commercialization is regarded to be a critical part of the innovation process, and most innovations fail in this phase (Aarikka-Stenroos et al., 2014). New products tend to fail if they cannot attract support from stakeholders, with customers being the ultimate determiners of the market success of a new product (Aarikka-Stenroos et al., 2014; Talke \& Hultink, 2010). Without a market, no matter how innovative a change, there will be no sales and the product is worthless (Winger \& Wall, 2006). One of the main factors that can impede customer acceptation of an innovation is uncertainty, and it could be in relation to expected benefits, the innovation's cost-value ratio or usage options (Talke \& Hultink, 2010). It is considered that the greater the level of societal or market sophistication and knowledge around the innovation, the greater the likelihood of the adoption (Menna \& Walsh, 2019). Commercialization network refers to an extensive group of actors who contribute to the commercialization of an innovation, and network aspect in commercialization is regarded to be crucial (Aarikka-Stenroos et al., 2014; Aarikka-Stenroos et al., 2012). For a successful innovation process, interacting parties need to have similar priorities, as well as similar or complementary interests and interaction goals (Öberg \& Shih, 2014).

In the commercialization of the variety 'Kornelija' multiple stakeholder groups can be distinguished - seed producers, barley farmers, barley processing companies, sellers and food consumers. This paper focuses on barley producing farms as the primary customers (buyers of the seeds of the variety) and food processors as the secondary customers (buyers of the grains), the latter also acting as the pullers of the primary demand. Development and introduction of new crop varieties are essential for the long-term profitability of farmers, and traditional varieties can be improved by enhancing product quality or increasing production efficiency and thereby reducing costs (Akhundjanov et al., 2019). In the case of the new variety 'Kornelija', it is a particular challenge for the commercialization to convince the food industry that the grain of the new variety is a valuable and economic raw material that can be used both to improve the existing products and to create new functional and dietary products, by this generating the necessary primary demand by farmers for the seeds of the variety and thus overcoming the barriers of market entry.

This study aims to meet the specific objectives: to define the main opportunities and challenges for the commercialization of the new hulless barley variety 'Kornelija' arising from its biochemical and farming profile; and to present the evaluation for the approach to a new protein-based payment system that would motivate farmers and allow varieties meeting expectations of food consumers to enter the market.

\section{Materials and Methods}

The primary market of the hulless variety 'Kornelija' are farmers (seed and grain producers). The secondary market that may create the demand for the hulless barley grain as a raw material for food production are grain processors and food manufacturers. Revenue for the inventors of the variety would be generated in the form of proceeds from the royalties for the use of the variety for commercial purposes in agriculture (Figure 1).

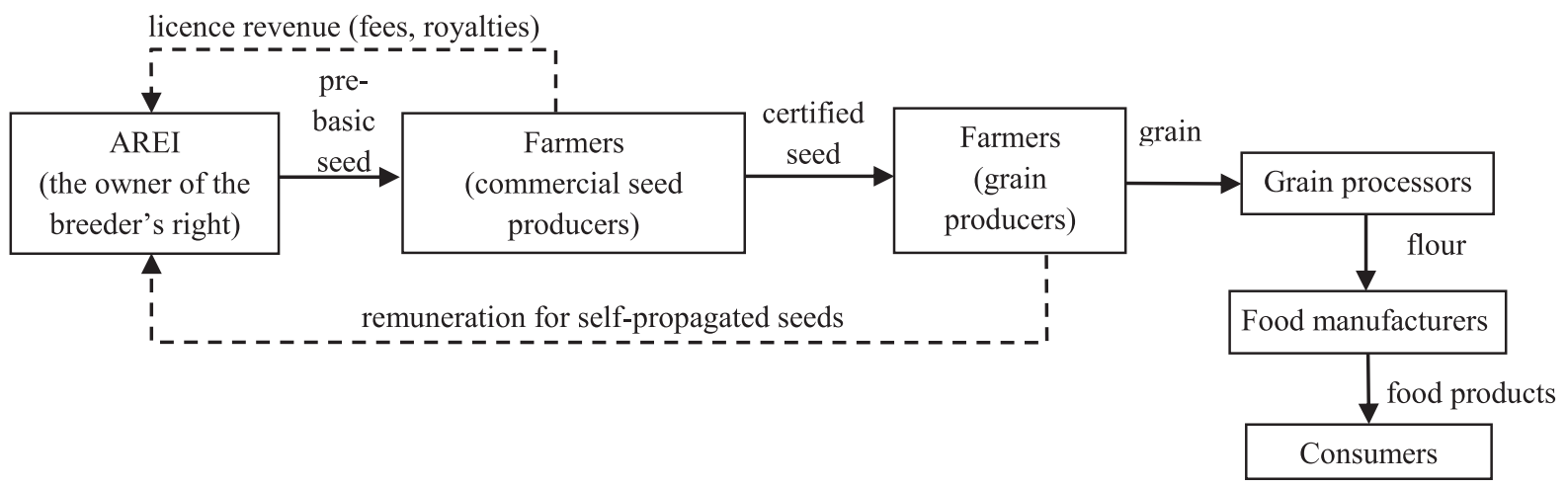

Figure 1. Market entry scheme for hulless barley variety 'Kornelija'. 
Considering that the market entry and primary demand for the new variety 'Kornelija' is formed as a derivative of the secondary demand, multi-level activities were implemented during the study by applying different methods suited to the purpose of each activity:

1) to develop cultivation technology and specify crop management measures for optimal yield, higher grain quality and reduced cultivation risks, field trials for several years have been implemented, improving the knowledge necessary for farmers about the new variety and its agricultural properties.

2) to obtain arguments for food processors, the biochemical profile of 'Kornelija' grain was analysed and compared to other hulless barley varieties, confirming the opportunities and superiority of the new variety among analogue products available on the EU market.

3) to motivate farmers to choose the variety (justify that 'Kornelija' grain is not just nutritionally valuable but can also be grown economically viable), the cost-effectiveness assessment of 'Kornelija' cultivation has been carried out. For this purpose, gross margins of different cultivation technologies of 'Kornelija' were calculated and compared to other cereals, serving to the proposition of the approach to proteinoriented pricing.

Evaluation of agronomic performance and cultivation technology development

Hulless barley variety 'Kornelija' (breeder's reference IC360) has been created at the State Stende Cereal Breeding Institute (since 2016 Stende Research Centre, AREI).

In 2004, an individual selection of plants was done from the F4 generation hybrid population (cross combination SCBN852.7/Sauce/3/Mola/Schuri//Arupo*2/Jet) which was received from the International Center for Agricultural Research in the Dry Areas (ICARDA) in 2003 within the framework of the breeding material exchange programme. The results of agronomic performance in the long-term field trials obtained for the hulless barley variety 'Kornelija' were carried out from 2015 to 2019 at Stende Research Centre, AREI (location N 57. $1^{\circ}, \mathrm{E} 22.5^{\circ}$ ). The field trials provide the data on yield potential, grain quality, lodging and disease resistance and serve as arguments for offering the new variety to farmers.

The soil for the trials was a sod podzolized sandy loam
Albeluvisol (Eutric); organic matter: $22-26 \mathrm{~g} \mathrm{~kg}^{-1}, \mathrm{pH} \mathrm{KCl} \mathrm{-}$ $5.9-6.3, \mathrm{P}_{2} \mathrm{O}_{5}$ content $168-182 \mathrm{mg} \cdot \mathrm{kg}^{-1}$ and $\mathrm{K}_{2} \mathrm{O} 175-250$ $\mathrm{mg} \cdot \mathrm{kg}^{-1}$. The rate of the complex mineral fertilizer and nitrogen fertilizer in the form of ammonium nitrate used in the experiments was calculated in the pure substance: $\mathrm{N} 80$ - 85 $\mathrm{kg} \cdot \mathrm{ha}^{-1}, \mathrm{P}_{2} \mathrm{O}_{5} 40-45 \mathrm{~kg} \cdot \mathrm{ha}^{-1}$ and $\mathrm{K}_{2} \mathrm{O} 40-70 \mathrm{~kg} \cdot \mathrm{ha}^{-1}$, and applied in the soil before sowing. Sowing (400 germinable seeds per $\mathrm{m}^{2}$ ) was done at optimal time in late April or early May. Herbicides were used for weed control in the trials without fungicide application. Vegetation period was determined. Plant lodging and symptoms of fungal diseases powdery mildew (Blumeria graminis) and net blotch (Pyrenophora teres) were assessed. 1000 grain weight (TGW) was determined by ISTA method, protein and test weigh were analyzed by the automatic grain analyzer Infratec NOVA(Foss, Denmark).

Another field trial with the purpose to set up an optimal cultivation technology for the variety 'Kornelija' in the conventional farming system was carried out in 2019 (sown on April 18). The field experiment was established on a sod podzolized sandy loam Albeluvisol (Eutric) in split plot design on plots of $20 \mathrm{~m}^{2}$ in 4 replications. The soil was an acidic to slightly acidic $\mathrm{pH}$ ( $\mathrm{pH}$ KCL 4.9 - 5.7), organic matter $20-25 \mathrm{~g} \cdot \mathrm{kg}^{-1}$, contained $158-219 \mathrm{mg} \cdot \mathrm{kg}^{-1} \mathrm{P}_{2} \mathrm{O}_{5}$ and $169-182$ $\mathrm{mg} \cdot \mathrm{kg}^{-1} \mathrm{~K}_{2} \mathrm{O}$, pre-crop - potatoes.

In total, 15 technologies were established applying different agrotechnical measures, such as sowing rate, fertilization rate, fertilisation regime, including 6 technologies without application of fungicides $(F)$ and retardants $(R)$ and 9 technologies with the application of $\mathrm{F}$ and $\mathrm{R}$. The fertilization rates by application of complex fertiliser NPKS 8:20:30:2 and ammonium sulphate nitrate NS 30:7 were planned based on soil agrochemical analyses to obtain expected yield levels of $3.0,4.0$ or $5.0 \mathrm{t} \cdot \mathrm{ha}^{-1}$ (Table 1 ). The following variants of the cultivation technologies were applied: $3.0 \mathrm{t} \cdot \mathrm{ha}^{-1}$ without $\mathrm{F}$ and $\mathrm{R} ; 4.0 \mathrm{t} \cdot \mathrm{ha}^{-1}$ with and without $\mathrm{F}$ and $\mathrm{R} ; 5.0 \mathrm{t} \cdot \mathrm{ha}^{-1}$ with and without $\mathrm{F}$ and $\mathrm{R}$. These five cultivation technologies were applied under three sowing rates 400,450 and 500 germinable seeds per $\mathrm{m}^{2}$. Nitrogen application for the cultivation technology with expected yield $5 \mathrm{t} \cdot \mathrm{ha}^{-1}$ was split, top-fertilizer ammonium sulphate nitrate NS 30:7 was used in the beginning of stem elongation phase (BBCH 30) in the amount $30 \mathrm{~kg} \mathrm{~N} \cdot \mathrm{ha}^{-1}$ and $7 \mathrm{~kg} \mathrm{~S} \cdot \mathrm{ha}^{-1}$.

Table 1

\section{Characterization of fertilization rates and plant protection products applied for expected variety 'Kornelija' yield levels of 3.0, 4.0 and $5.0 \mathrm{t} \mathrm{ha}^{-1}, 2019$}

\begin{tabular}{|c|c|c|c|}
\hline \multirow{2}{*}{ Specification } & \multicolumn{3}{|c|}{ Expected yield, $\mathrm{t} \cdot \mathrm{ha}^{-1}$} \\
\hline & 3.0 & 4.0 & 5.0 \\
\hline \multicolumn{4}{|c|}{ Fertilizer in pure form, $\mathrm{kg} \cdot \mathrm{ha}^{-1}$} \\
\hline $\mathrm{N}$ & $53\left(\mathrm{BBCH}^{\mathrm{a}} 0\right)$ & $72(\mathrm{BBCH} 0)$ & 61 (BBCH 0); 30 (BBCH 30) \\
\hline $\mathrm{P}$ & $20 \mathrm{P}_{2} \mathrm{O}_{5}$ & $30 \mathrm{P}_{2} \mathrm{O}_{5}$ & $40 \mathrm{P}_{2} \mathrm{O}_{5}$ \\
\hline $\mathrm{K}$ & $30 \mathrm{~K}_{2} \mathrm{O}$ & $45 \mathrm{~K}_{2} \mathrm{O}$ & $60 \mathrm{~K}_{2} \mathrm{O}$ \\
\hline $\mathrm{S}$ & 13 & 17 & 15 (BBCH 0); 7 (BBCH 30) \\
\hline \multicolumn{4}{|c|}{ Pesticides } \\
\hline Herbicides & \multicolumn{3}{|c|}{$\begin{array}{l}\text { BBCH 28: amidosulfuron, jodosulfuron }\left(1.3 \mathrm{~kg} \cdot \mathrm{ha}^{-1} ; \text { May } 17\right) \\
\text { BBCH 33: florasulam, tritosulfuron } 60 \mathrm{~g} \cdot \mathrm{ha}^{-1} \text { and surfactant }\left(0.5 \mathrm{~L} \cdot \mathrm{ha}^{-1} ; \text { June } 4\right)\end{array}$} \\
\hline Fungicides (F) & - & \multicolumn{2}{|c|}{ BBCH 32: bixafen, prothioconazole, fluoxastrobin $\left(1.0 \mathrm{~L} \cdot \mathrm{ha}^{-1} ;\right.$ May 30$)$} \\
\hline Retardant (R) & - & \multicolumn{2}{|c|}{ BBCH 32: trineksapak-etil $\left(0.4 \mathrm{~L}^{\prime} \mathrm{ha}^{-1}\right.$; May 30$)$} \\
\hline
\end{tabular}

${ }^{a} \mathrm{BBCH}$ - cereal growth stage scale (Lancashire et al., 1991) 
Date of heading was on June 15, maturity reached on July 25 and harvesting on July 2 in 2019 . Yield was estimated at $100 \%$ purity and $14 \%$ moisture. The samples for analysing the grain quality were taken from each plot. The following grain physical traits were evaluated: TGW (g) by ISTA method, test weight $\left(g \cdot \mathrm{L}^{-1}\right)$ by grain analyser Infratec NOVA (Foss, Denmark) and crude protein content $\left(\mathrm{g} \cdot \mathrm{kg}^{-1}\right)$ by grain analyser Infratec NOVA (Foss, Denmark). All indicators were expressed on a dry matter basis.

Two-way ANOVA and methods of descriptive statistics were applied for the statistical data analysis.

\section{Evaluation of biochemical composition}

Grain samples of varieties 'Kornelija', 'Irbe', 'Pihl', Naku', 'Gawrosh' were obtained from the breeders in 2018, which means they were cultivated in the conditions of their origin country. In order to obtain the grain harvest cultivated in the same agroclimatic conditions, in 2019 these varieties were grown at Stende Research Centre, AREI in the multiplication trial by $2 \mathrm{~m}^{2}$ plots in 2 replications.

Grain subsamples from each replications (in the period sample from 2015 to 2019) were combined to form the composite. The composite sample was blended by shaking to form the laboratory sample $(0.5 \mathrm{~kg})$ for testing in order to evaluate the average content of protein, fibre, starch and amino acids.

Protein content was determined by the Kjeldahl method and conversation factor 6.25 was applied to convert total nitrogen to crude protein. The content of starch was determined according to LVS EN ISO 10520:2001. The content of total $\beta$-glucans was determined in agreement with ICC Standard Method No.168 for assessing mixed-linkage $\beta$ glucans by using Megazyme Assay Kits. Determination of total dietary fibre (TDF) based on AOAC Method 991.43 by using Megazyme assay procedure. The content of lipid was determined by Soxlet method.

In order to examine the composition of the amino acids, the grain test samples have been dried and defatted and treated with constant boiling $6 \mathrm{~N}$ hydrochloric acid in the oven at around $110^{\circ} \mathrm{C}$ for $23 \mathrm{~h}$. Hydrolysate was diluted with $0.1 \%$ formic acid. Amino acids were detected using reversedphase HPLC/MS Mobile phase (90\% acetonitrile: $10 \%$ deionized water) $0.5 \mathrm{~mL} \cdot \mathrm{min}^{-1}$, column temperature at $400{ }^{\circ} \mathrm{C}$ was used. The identity and quantitative analysis of the amino acids were assessed by comparison with the retention times and peak areas of the standard amino acid mixture.

The sum of all amino acids (AA) and essential amino acids (EAA) was calculated by the following formulae:

$$
\begin{gathered}
A A=\text { Asp }+ \text { Glu }+ \text { Ser }+ \text { Gly }+ \text { Arg }+ \text { Ala }+ \text { Pro }+ \text { Tyr }+ \text { Thr }+ \\
+ \text { Val }+ \text { Met }+ \text { Ile }+ \text { Leu }+ \text { Phe }+ \text { His }+ \text { Lys } \\
E A A=\text { Thr }+ \text { Val }+ \text { Met + Ile + Leu + Phe + His + Lys },
\end{gathered}
$$

where Asp - aspartic acid; Glu - glutamic acid; Ser - serine; Gly - glycine; Arg - arginine; Pro - proline; Tyr - tyrosine; Thr - threonine, Val - valine, Met - methionine, Ile isoleucine, Leu - leucine, Phe - phenylalanine, His histidine, Lys - lysine.

A-tocopherol as tocol with highest vitamin E activity was determined using high-performance liquid-chromatography according to ISO 9936-2006.

\section{Economic evaluation}

The economic evaluation has been carried out in two stages, based on the information from the field trials, evaluation of the biochemical composition, as well as Agricultural gross margin calculations for 2019 by Latvian Rural Advisory and Training Centre (LRAT) (2020).

First, all 15 cultivation technologies of 'Kornelija' examined in the field trials have been evaluated in order to identify the most cost-efficient (with the lowest production costs) technology (considering different sowing rates, fertilization rates, fertilization regimes and use of plant protection products).

To assess full variable costs of the cultivation, the costs of seed, fertilizers, plant protection products, machinery operations, grain cleaning, grain drying and grain transportation were calculated. Prices of seed and fertilizers per tonne, costs of pesticides (herbicides, fungicides and retardants) and machinery operations per hectare, as well as the costs of grain cleaning, grain drying and transportation per tonne reported in Agricultural gross margin calculations for 2019 are used as reference or standard prices and unit costs to calculate the total variable costs of cultivation of the new hulless barley variety 'Kornelija'. Presently, the seed of 'Kornelija' is not available on the market, however, it is assumed that the price for its seed will be similar to the seed price of other barley varieties (standard price of barley seed is used).

Full variable costs of cultivation were expressed per tonne of grains, complemented by calculations also per tonne of protein and per tonne of $\beta$-glucans.

Second, in order to develop an approach for the new proteinbased payment system, two most cost-efficient technologies of 'Kornelija' cultivation have been compared to the typical cereal crops - spring wheat, winter wheat, oats, hulled barley (when typical cultivation technology is applied). As 'Kornelija' competes both in protein and $\beta$-glucans, the competitiveness is evaluated considering the content of protein and $\beta$-glucans provided by 'Kornelija' and the other cereal crops.

Generally, farmers choose to grow crops that provide an adequate margin (income) per hectare. The gross margins of typical cereal crops in Latvia are presented in Table 2 (margins are without public support (e.g., single area payments, greening payments)). 
Calculation of gross margin for typical cereal crops in Latvia, 2019

Table 2

\begin{tabular}{|c|c|c|c|c|}
\hline Indicators & $\begin{array}{l}\text { Spring } \\
\text { wheat }\end{array}$ & $\begin{array}{l}\text { Winter } \\
\text { wheat }\end{array}$ & Oats & $\begin{array}{l}\text { Hulled } \\
\text { barley }\end{array}$ \\
\hline \multicolumn{5}{|l|}{ Revenue: } \\
\hline Yield, $\mathrm{t} \cdot \mathrm{ha}^{-1}$ & 4.2 & 6.2 & 3.0 & 3.8 \\
\hline Price, EUR $\cdot t^{-1}$ & 162 & 162 & 157 & 134 \\
\hline Total revenue, EUR $\cdot \mathrm{ha}^{-1}$ & 680 & 1004 & 471 & 508 \\
\hline \multicolumn{5}{|l|}{ Costs: } \\
\hline Seed, EUR $\cdot \mathrm{ha}^{-1}$ & 66 & 69 & 58 & 67 \\
\hline Fertilizer, EUR $\cdot$ ha $^{-1}$ & 109 & 164 & 69 & 95 \\
\hline Pesticides, EUR $\cdot$ ha $^{-1}$ & 36 & 86 & 13 & 47 \\
\hline Machinery operations, EUR $\cdot \mathrm{ha}^{-1}$ & 269 & 306 & 229 & 249 \\
\hline Grain cleaning, EUR $\cdot \mathrm{ha}^{-1}$ & 14 & 20 & 10 & 13 \\
\hline Grain drying, EUR $\cdot \mathrm{ha}^{-1}$ & 34 & 51 & 25 & 31 \\
\hline Transport costs, EUR $\cdot$ ha $^{-1}$ & 13 & 19 & 9 & 11 \\
\hline Total variable costs, EUR $\cdot$ ha $^{-1}$ & 540 & 714 & 413 & 513 \\
\hline Gross margin, EUR $\cdot \mathrm{ha}^{-1}$ & 140 & 290 & 58 & -6 \\
\hline
\end{tabular}

Source: LRAT, 2020

Winter wheat and spring wheat have the highest gross margins, which is the main reason why farmers prefer to grow wheat, especially winter wheat, in Latvia. Thus, the gross margin of wheat can be regarded as the reference margin that determines the farmers' choice to cultivate certain crops.
Therefore, it is assumed that the price for the grains of 'Kornelija' offered to farmers by grain processors should be sufficient to ensure the reference margin, otherwise farmers would lack an incentive to choose 'Kornelija'. This breakeven price can be derived from the following equation:

$$
\Pi_{r}=P_{b} \cdot Q-C_{h a}-C_{t} \cdot Q,
$$

where $\Pi_{\mathrm{r}}$ stands for the reference margin, EUR $\cdot \mathrm{ha}^{-1}$;

$$
\begin{aligned}
& \mathrm{P}_{\mathrm{b}} \text { - break-even price, EUR } \cdot \mathrm{t}^{-1} ; \\
& \mathrm{Q}-\text { volume (yield), } \mathrm{t} \cdot \mathrm{ha}^{-1} ; \\
& \mathrm{C}_{\mathrm{ha}} \text {-costs-per-ha, EUR } \cdot \mathrm{ha}^{-1} ; \\
& \mathrm{C}_{\mathrm{t}} \text { - costs-per-tonne, EUR } \cdot \mathrm{t}^{-1} \text {. }
\end{aligned}
$$

Costs-per-ha $\left(\mathrm{C}_{\mathrm{ha}}\right)$ comprise costs of seed, fertilizer, pesticides and machinery operations, while costs-per-tonne $\left(\mathrm{C}_{t}\right)$ cover the costs of grain cleaning, grain drying and transportation.

Based on the equation (3), the following formula is derived to calculate $\mathrm{P}_{\mathrm{b}}$ :

$$
\mathrm{P}_{b}=C_{t}+\frac{C_{h a}+\Pi_{r}}{Q}
$$

As there is uncertainty about the direct payment support schemes in the next programming period to ensure more cautious estimates, the coupled support that is currently available for barley was not included in the calculation of $\mathrm{P}_{\mathrm{b}}$. As $\Pi_{r}$ is determined by the price for the reference crop (e.g., spring and winter wheat), $\mathrm{P}_{\mathrm{b}}$ should be interpreted along the price for the reference crop. Changes in the reference price affect $\Pi_{r}$ and $\mathrm{P}_{b}$, though, the effect of the changes on $\mathrm{P}_{\mathrm{b}}$ is not proportional: e.g. $10 \%$ increase in the price for the reference crop does not necessarily cause $10 \%$ increase in $\mathrm{P}_{\mathrm{b}}$.

\section{Results and Discussion}

Agronomic performance - challenges and opportunities for farmers

From 2008 to 2011, the agronomic characteristics and basic grain quality traits for variety 'Kornelija' were assessed in several field trials of barley breeding programme. The average yield in the initial breeding trials for 'Kornelija' compared to standard varieties 'Irbe' (the first hulless barley variety registered in Latvia) and 'Ansis' (variety of hulled barley, registered and traditionally grown in Latvia) was significantly lower (Bleidere \& Grunte, 2015). However, agronomic advantages of the variety 'Kornelija' such as its earliness (showing on average 4 and 9 days shorter vegetation period than the standard varieties, respectively) and its coarse grain (1000-grain weight $48.6 \mathrm{~g}$ ) were observed. The grain test weight and resistance to leaf diseases were similar to the hulless standard variety 'Irbe'.

Multi-location testing remains one of the main tools for understanding varietal responses to environment and for studying yield stability of genotypes across different growing conditions. During two test years (2011 - 2012) in four locations (Stende (Latvia), Priekuli (Latvia), Dotnuva (Lithuania) and Jõgeva (Estonia)) the yield of the variety 
'Kornelija' varied from $3.01 \mathrm{t} \cdot \mathrm{ha}^{-1}$ to $5.24 \mathrm{t} \cdot \mathrm{ha}^{-1}$ (Bleidere \& Grunte, 2015). In these trials resistance to lodging varied from 5.2 to 9.0 scores depending on the year and growing location. Under different growing conditions, the prospective variety 'Kornelija' provided increased 1000-grain weight, crude protein and $\beta$-glucans content in grains compared to other hulless barley breeding lines (Bleidere et al., 2013a). Since 2014 the variety 'Kornelija' has been included in the Latvian Catalogue of Plant Varieties based on the results of Value for Cultivation and Use test which was completed from 2012 to 2013 at four growing sites in Latvia. Grain yield of the variety was $4.22 \mathrm{t} \cdot \mathrm{ha}^{-1}$ on average, it showed high lodging resistance ( 8.0 scores) and early ripening ( 3 days earlier than 'Irbe'). Also, valuable and useful for food innovation properties such as increased 1000-grain weight (49.3 g), test weight $\left(735 \mathrm{~g} \cdot \mathrm{L}^{-1}\right)$ and high protein content $\left(156 \mathrm{~g} \cdot \mathrm{kg}^{-1}\right)$ were observed (Bleidere \& Grunte, 2015).

Overall, the results of the long-term field trials under meteorologically different years from 2015 to 2019 also confirmed that the yield potential of the new variety 'Kornelija' is intermediate, but the variety has shorter vegetation period and provides coarse grains with increased 1000 -grain weight as well as shows medium resistance to powdery mildew and good resistance to net blotch. Although the average grain yield of the variety 'Kornelija' was significantly lower in comparison with the variety 'Irbe', protein yield $\left(\mathrm{t} \cdot \mathrm{ha}^{-1}\right)$ for both hulless varieties was at the same level (Table 3). No infection with loose smut was observed during the above-mentioned years of evaluation.

Table 3

\section{Characterization of agronomic traits for hulless barley variety 'Kornelija' in comparison with standard variety 'Irbe', 2015-2019}

\begin{tabular}{|l|c|c|c|c|}
\hline \multirow{2}{*}{\multicolumn{1}{|c|}{ Trait }} & \multicolumn{2}{|c|}{ 'Kornelija' } & \multicolumn{2}{c|}{ 'Irbe' } \\
\cline { 2 - 5 } & Average & min-max & Average & min-max \\
\hline Grain yield, $\mathrm{t} \cdot \mathrm{ha}^{-1}$ & $3.29^{\mathrm{a}}$ & $2.38-4.40$ & $4.21^{\mathrm{b}}$ & $2.90-5.30$ \\
\hline Vegetation period, days & $96^{\mathrm{a}}$ & $87-106$ & $100^{\mathrm{b}}$ & $92-106$ \\
\hline Lodging resistance, scores $^{\mathrm{c}}$ & $6.7^{\mathrm{a}}$ & 5.0 & $8.1^{\mathrm{a}}$ & $7.0-9.0$ \\
\hline 1000 -grain weight, g & $50.3^{\mathrm{a}}$ & $46.8-55.1$ & $45.1^{\mathrm{b}}$ & $42.6-46.9$ \\
\hline${\text { Test weight, } \mathrm{g} \cdot \mathrm{L}^{-1}}^{\text {Powdery mildew, scores }}{ }^{\mathrm{d}}$ & $808.2^{\mathrm{a}}$ & $762-817$ & $798.3^{\mathrm{a}}$ & $762-825$ \\
\hline Net blotch, scores $^{\mathrm{c}}$ & 2.2 & $0-5$ & 0.0 & 0.0 \\
\hline${\text { Protein yield, } \mathrm{t} \cdot \mathrm{ha}^{-1}}$ & 2.0 & $0-4$ & 1.8 & $0.36-3.0$ \\
\hline
\end{tabular}

${ }^{a, b}$ the means of traits among varieties followed by different letters are significantly different at $\mathrm{p}<0.05$ level.

' 1 - all plants are lodged; 9 - no signs of lodging.

d 0 - no signs of infection, 9 - very severe infection.

Source: data from the field trials (2015 - 2019), conventional conditions.

The new variety has been tested also under the conditions of organic farming. 'Kornelija' has showed significantly higher 1000-grain weight and higher protein content than other hulless varieties in organic farming field trials, as well as the yield potential was almost similar to other hulled and hulless barley varieties included in the experiments (Sturite et al., 2019). During some other field trials under the conditions of organic farming the tested genotypes were analysed by integral evaluation method according to grain yield and quality traits simultaneously with the aim to identify the varieties having the lowest deviation from the desired value for food production. The variety 'Kornelija' provided the best results among hulless barley varieties (Tamm etal., 2015).

In order to facilitate the commercialization of 'Kornelija' and to recommend the new variety as a high-nutrition raw material for food production, especially for niche or functional foods, it has been important to find the optimal cultivation technology and to evaluate the stability of its characteristics under the conditions of practical farming. The obtained results showed a good yield potential (above $4 \mathrm{t} \cdot \mathrm{ha}$ ${ }^{1}$ ) for the technology in which 'Kornelija' was cultivated without the application of fungicides and retardants and with a lower nitrogen fertilizer rate $\left(53 \mathrm{~kg} \cdot \mathrm{ha}^{-1}\right)$. The cultivation technologies with the application of all plant protection products provided significantly $(\mathrm{p}<0.05)$ higher yields for variety 'Kornelija'. Increased and split rate $(\mathrm{N} 61+30)$ of $\mathrm{N}$ fertiliser provided significant yield increase (Table 4). Within this approach, the grain yield of 'Kornelija' exceeded 5.0 $\mathrm{t} \cdot \mathrm{ha}^{-}$ ${ }^{1}$ when the applied mineral nitrogen fertiliser rate was 72 $\mathrm{kg} \cdot \mathrm{ha}^{-1}$, and the highest grain yield of $5.48 \mathrm{t} \cdot \mathrm{ha}^{-1}$ was obtained in the cultivation technology where the split mineral fertiliser $\mathrm{N}$ dose $\left(\mathrm{N} 61+30 \mathrm{~kg} \cdot \mathrm{ha}^{-1}\right)$ was applied (Table 4). 
Table 4

\section{Effect of sowing rate, fertilization rate and plant protection product application on agronomic traits, 2019}

\begin{tabular}{|c|c|c|c|c|c|c|}
\hline \multirow[t]{2}{*}{$\begin{array}{l}\text { Sowing rate, } \\
\text { germinable seeds per } \\
\mathrm{m}^{2}\end{array}$} & \multicolumn{3}{|c|}{$\begin{array}{c}\text { Technologies without application of } \\
\text { fungicides and retardants, expected yield, } \\
\qquad \mathrm{t} \cdot \mathrm{ha}^{-1}\end{array}$} & \multicolumn{2}{|c|}{$\begin{array}{l}\text { Technologies with } \\
\text { application of } \\
\text { fungicides and } \\
\text { retardants, expected } \\
\text { yield, } \mathrm{t} \cdot \mathrm{ha}^{-1}\end{array}$} & \multirow[t]{2}{*}{ Average } \\
\hline & 3.0 & 4.0 & 5.0 & 4.0 & 5.0 & \\
\hline \multicolumn{7}{|c|}{ Grain yield, $\mathrm{t} \cdot \mathrm{ha}^{-1} ; \mathrm{LSD}_{\mathrm{p}<0.05}$ Sowing rate $=0.151 ; \mathrm{RS}_{0.05}$ Cultivation technology $=0.195$} \\
\hline 350 & 4.03 & 4.29 & 4.43 & 5.16 & 5.43 & $4.67^{\mathrm{a}}$ \\
\hline 400 & 4.23 & 4.25 & 4.33 & 5.13 & 5.40 & $4.67^{\mathrm{a}}$ \\
\hline 450 & 4.43 & 4.33 & 4.48 & 5.20 & 5.61 & $4.81^{\mathrm{a}}$ \\
\hline Average & $4.23^{d}$ & $4.29^{\mathrm{cd}}$ & $4.41^{\mathrm{c}}$ & $\mathbf{5 . 1 6}^{\mathrm{b}}$ & $5.48^{\mathrm{a}}$ & 4.72 \\
\hline \multicolumn{7}{|c|}{ Lodging resistance, scores $^{\mathrm{e}} ; \mathrm{LSD}_{\mathrm{p}<0.05}^{\mathrm{g}}$ Sowing rate $=0.432 ; \mathrm{RS}_{0.05}$ Cultivation technology $=0.558$} \\
\hline 350 & 7.3 & 7.3 & 6.0 & 9 & 8.5 & $7.6^{\mathrm{a}}$ \\
\hline 400 & 7 & 7.5 & 5.8 & 9 & 7.3 & $7.3^{a}$ \\
\hline 450 & 8 & 8 & 6.5 & 9 & 7.8 & $7.9^{a}$ \\
\hline Average & $7.4 c$ & $7.6 \mathrm{bc}$ & $6.1 d$ & $9.0 \mathrm{a}$ & $7.9 \mathrm{~b}$ & 7.6 \\
\hline \multicolumn{7}{|c|}{ Symptoms of powdery mildew, scores ${ }^{\mathrm{f}} ; \mathrm{LSD}_{\mathrm{p}<0.05}$ Sowing rate $=0.660 ; \mathrm{RS}_{0.05}$ Cultivation technology $=0.536$} \\
\hline 350 & 6.0 & 5.0 & 6.0 & 0.0 & 0.0 & $3.4^{\mathrm{a}}$ \\
\hline 400 & 6.0 & 7.0 & 5.0 & 2.0 & 0.0 & $4.0^{\mathrm{a}}$ \\
\hline 450 & 6.0 & 6.0 & 6.0 & 0.0 & 0.0 & $3.6^{\mathbf{a}}$ \\
\hline Average & $6.0 \mathrm{a}$ & 6.0a & $5.7 \mathbf{a}$ & $\mathbf{0 . 7 b}$ & $0.0 \mathrm{c}$ & 3.7 \\
\hline \multicolumn{7}{|c|}{ 1000-grain weight, g; $\mathrm{LSD}_{\mathrm{p}<0.05}$ Sowing rate $=0.795 ; \mathrm{RS}_{0.05}$ Cultivation technology $=1.027$} \\
\hline 350 & 47.7 & 49.6 & 47.9 & 49.1 & 50.8 & $49.0^{\mathrm{a}}$ \\
\hline 400 & 48.2 & 48.2 & 47.3 & 49.3 & 51.3 & $48.9^{a}$ \\
\hline 450 & 48.8 & 48 & 48.6 & 49.0 & 50.9 & $49.1^{\mathrm{a}}$ \\
\hline Average & $48.2^{b c}$ & $48.6^{b c}$ & $47.9^{c}$ & $49.1^{b}$ & $51.0^{\mathrm{a}}$ & 49.0 \\
\hline
\end{tabular}

${ }_{a, b, c, d}$ the means of traits among different technologies (sowing rate and expected yield) by different letters are significantly different at $\mathrm{p}<0.05$ level.

' 1 - all plants are lodged; 9 - no signs of lodging.

${ }^{\mathrm{f}} 0$ - no signs of infection, 9 - very severe infection.

${ }^{\mathrm{g}}$ the least significant difference.

Previous studies have also shown that hulless barley variety 'Kornelija' grown in conditions with higher input of mineral fertilizers can reach higher yields. Thus, by increasing nitrogen from 80 to $120 \mathrm{~kg} \cdot \mathrm{ha}^{-1}$ and by applying it as a top-dressing fertilizer, the grain yield increased significantly (from 2.73 to $3.50 \mathrm{t} \cdot \mathrm{ha}^{-1}$ ) (Bleidere et al., 2013b).

The variety's lodging-resistance between different technologies ranged from 6.0 to 9.0 scores. Applications of a retardant significantly increased lodging resistance of variety (Table 4). However, the use of plant growth regulators should only be recommended for the technologies with increased $\mathrm{N}$ fertiliser rates.

In 2019 which was considered to be a favourable year for the development of plant diseases, the hulless barley variety 'Kornelija' under the technologies without application of fungicides has shown moderate resistance to powdery mildew (Table 4). The use of fungicides has been comparatively effective in limiting the spread of the disease in the crop, providing significant yield increase. Significantly higher 1000-grain weight was obtained under the technology with the application of all plant protection products and the split mineral fertiliser $\mathrm{N}$ dose $\left(\mathrm{N} 61+30 \mathrm{~kg} \cdot \mathrm{ha}^{-1}\right)$. In turn, various sowing rates did not show the significant difference in grain yield and in other agronomic traits in any of the fertilisation options. It means that the cultivation costs of the variety 'Kornelija' can be reduced by applying lower sowing rate of $350 \mathrm{~g} \cdot \mathrm{m}^{-2}$.

Grain biochemical composition - prospects for the development

Unlike the agricultural profile of the variety with both advantages and disadvantages, it clearly shows good properties in terms of biochemical composition. As for all cereals, the grain biochemical composition of the hulless barley 'Kornelija' depends on farming system, growing and meteo-conditions and differs by years (Bleidere et al., 2013b; Tamm et al., 2015; Sturite et al., 2019). The results of the laboratory tests showed that the protein content of the 'Kornelija' grain harvested in 2018 and 2019 varied from $13.5 \%$ to $20.8 \%$ with the highest level observed in 2018 (Table 5), but even the lowest content of protein observed in field trial of organic farming is higher than the average protein content in hulled barley $(9-11.5 \%)$. 
Grain biochemical composition of hulless barley 'Kornelija', 2018 - 2019

\begin{tabular}{|c|c|c|c|c|c|c|c|c|c|}
\hline Year & $\begin{array}{c}\text { Protein, \% } \\
\text { in DM }\end{array}$ & $\begin{array}{c}\beta \text {-glucans, } \\
\% \text { in DM }\end{array}$ & $\begin{array}{c}\text { Starch, } \\
\% \text { in DM }\end{array}$ & $\begin{array}{c}\text { TDF, } \\
\%\end{array}$ & $\begin{array}{c}\text { Total } \\
\text { sugars, \% } \\
\text { in DM }\end{array}$ & $\begin{array}{c}\text { Total } \\
\text { fat, \% } \\
\text { in DM }\end{array}$ & $\begin{array}{c}\text { EAA/ } \\
\text { AA }\end{array}$ & $\begin{array}{c}\text { Sum of } \\
\text { EAA, } \\
\mathrm{g}^{\circ} \mathrm{kg}^{-1}\end{array}$ & $\begin{array}{c}\text { Vitamin E, } \\
\mathrm{mg}^{-100 \mathrm{~g}^{-1}}\end{array}$ \\
\hline $2018^{\mathrm{a}}$ & 20.84 & 6.15 & 47.91 & 17.4 & 1.88 & 2.11 & 30.0 & 51.4 & 0.8 \\
\hline $2019^{\mathrm{a}}$ & 16.40 & 4.90 & 59.99 & 19.5 & 0.95 & 2.00 & 32.0 & 42.9 & 0.6 \\
\hline $2019^{\mathrm{b}}$ & 13.53 & 4.38 & 62.27 & 26.3 & 1.00 & - & 33.0 & 36.3 & 0.7 \\
\hline
\end{tabular}

${ }^{a}$ mean value, data from the field trial, conventional conditions.

${ }^{\mathrm{b}}$ mean value, data from the field trial, organic farming conditions.

The grain biochemical composition of 'Kornelija' is comparable to the hulless barley parameters reported by other researchers (Arendt \& Zannini, 2013; Baik \& Ullrich, 2008; Biel \& Jacyno, 2013). The protein content of hulless barley grains usually accounts for 8 to $17 \%, \beta$-glucans - for 3.6 to $9 \%$ and total dietary fibre is 11 to $34 \%$ (Arendt \& Zannini, 2013). Based on nutrition point of view, hulless barley is a winner as compared to hulled barley, it is rich in fiber, comprises essential minerals and vitamins, lower in fat content as well as cholesterol free, therefore, hulless barley is preferred in foods (Shaveta et. al, 2019).

The fibre, particularly soluble fibre $\beta$-glucans in a diet reduces cholesterol level in human blood (Havrlentova et al., 2011), which improves cardiovascular disease prevention. The results of research (Mitsou et al., 2010) suggest that barley $\beta$-glucans help prevent gut inflammation diseases as well as fight certain forms of cancer.

Typically with the increase of protein in grains, the amount of starch and fibre including $\beta$-glucans decreases (Biel \& Jacyno, 2013), while the evaluation of biochemical composition of the grain of 'Kornelija' showed a unique trait of the variety - ability to produce high level of $\beta$-glucans along with high protein content in grain samples, this correlation was positive, weak but significant $(\mathrm{p}<0.05)$ (Sterna et al., 2015; Sterna et al., 2017). It could be connected with the fact that $\beta$-glucans in the endosperm cell walls may be covalently bound to protein, forming large molecules of $107 \mathrm{Da}$ (Macdougall and Selvendran, 2001). It is characteristic for varieties with high potential of protein content (Paynter \& Harasymow, 2010).

According to the World Health Organisation and United
Nations University joint report, the dietary properties of protein are related to the concentration of essential amino acids in protein, compared with their nutritional requirements in the human body (World Health Organisation \& United Nations University, 2007). The evaluation of protein quality showed that the sum of amino acids, essential for human health found in the grains of 'Kornelija' was about $25 \%$ of protein content. The sum of essential amino acids varied from 36.3 to $51.4 \mathrm{mg} \cdot \mathrm{kg}^{-1}$ and the ratio of essential amino acids to total-EAA/AA varied from 30.0 to 33.0 (Table 5).

High protein content and the sum of essential amino acids, as well as high dietary fibre content are the main reasons to consider the grains of 'Kornelija' as a perfect raw material for healthy food products and functional food production. The hulless barley variety 'Kornelija' may not only replace the currently used raw materials in functional food production, but also become a source of inspiration for development of new food products and the implementation thereof in production.

Although the availability of hulless barley on the market is not yet widespread, there can be found some varieties of hulless barley on the EU market that could be considered as competitors of 'Kornelija'. During the implementation of the commercialization process, in order to substantiate the superiority of the grains of 'Kornelija' over other hulless barley varieties, grain biochemical composition of variety 'Kornelija' was compared also with some other hulless barley varieties currently offered in the EU market such as Irbe (Latvia), 'Pihl' (Norway), 'Gawrosz' (Poland) and 'Naku' (Sweden) (Table 6).

Table 6

\section{Comparison of grain biochemical profile of different hulless barley varieties, 2018 - 2019}

\begin{tabular}{|l|c|c|c|c|c|}
\hline \multicolumn{1}{|c|}{ Nutrients } & Kornelija & Irbe & Pihl & Gawrosz & Naku \\
\hline \multirow{2}{*}{ Protein content, \% in DM } & 20.84 & 13.90 & 11.61 & 16.32 & 14.06 \\
\cline { 2 - 6 } & $20.39^{\mathrm{a}}$ & $15.33^{\mathrm{a}}$ & $19.60^{\mathrm{a}}$ & $17.44^{\mathrm{a}}$ & $16.44^{\mathrm{a}}$ \\
\hline \multirow{2}{*}{$\beta$-glucans content, \% in DM } & 6.15 & 3.80 & 4.35 & 4.50 & 4.01 \\
\cline { 2 - 6 } & $5.04^{\mathrm{a}}$ & $4.83^{\mathrm{a}}$ & $4.97^{\mathrm{a}}$ & $5.01^{\mathrm{a}}$ & $4.76^{\mathrm{a}}$ \\
\hline \multirow{2}{*}{ Starch, \% in DM } & 47.91 & $\ldots^{\mathrm{b}}$ & 63.18 & $\ldots^{\mathrm{b}}$ & 57.68 \\
\hline Total dietary fibre, \% in DM & $56.39^{\mathrm{a}}$ & $60.25^{\mathrm{a}}$ & $56.75^{\mathrm{a}}$ & $57.40^{\mathrm{a}}$ & $57.94^{\mathrm{a}}$ \\
\hline Total sugars, \% in DM & 17.4 & 16.9 & 17.9 & 19.6 & 21.5 \\
\hline Total fat, \% in DM & 1.88 & 1.00 & 1.15 & 3.40 & 1.75 \\
\hline
\end{tabular}




\begin{tabular}{|l|c|c|c|c|c|}
\hline Ash, \% & 2.63 & 2.10 & 2.01 & 2.20 & 2.27 \\
\hline Vitamin E, $\mathrm{mg} \cdot 100 \mathrm{~g}^{-1}$ & 0.8 & 0.9 & 0.8 & 0.6 & 0.7 \\
\hline The sum of EAA, $\mathrm{g} \cdot \mathrm{kg}^{-1}$ & 51.4 & 39.1 & 32.6 & 42.4 & 40.8 \\
\hline
\end{tabular}

a data of the yield in 2019.

${ }^{\mathrm{b}}$ reliable data were not available.

Data shows that analysed nutrients for samples of hulless varieties included in this study are found in different proportions. The protein content and also $\beta$-glucans in grain of 'Kornelija' were the highest among the examined varieties both in 2018 and in 2019. Consequently, the grain of
'Kornelija' had the highest sum of amino acids and the highest sum of essential amino acids as well. The composition of essential amino acids in the tested hulless barley varieties is reflected in Figure 2.

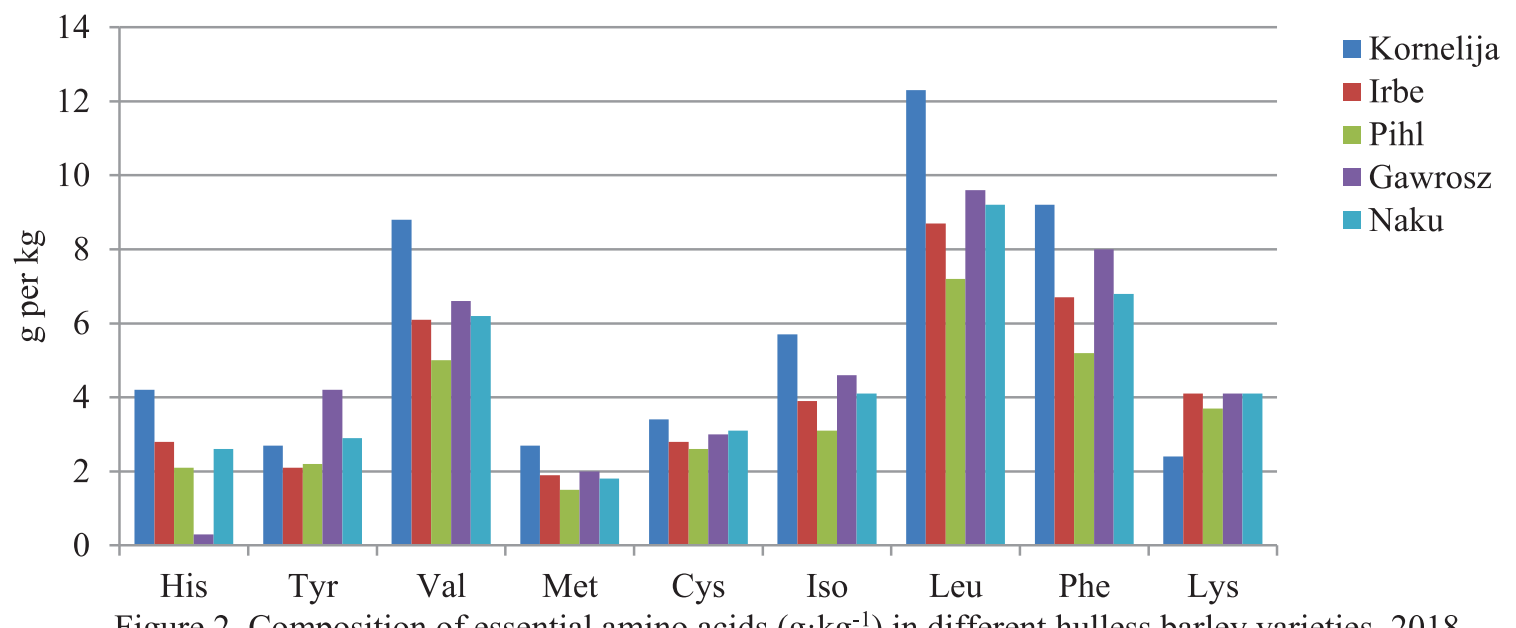

Figure 2. Composition of essential amino acids $\left(\mathrm{g} \cdot \mathrm{kg}^{-1}\right)$ in different hulless barley varieties, 2018 .

The comparison of essential amino acids in the samples of hulless barley varieties shows especially high leucine, isoleucine, valine and histidine content in the 'Kornelija' grain. Lysine was the only amino acid determined less in the 'Kornelija' than in other varieties. Overall, the nutritional quality of barley protein has been evaluated as moderate that is mainly due to the high proportion of hordeins that for barley with high protein is typically higher (Baik \& Ullrich, 2008).

During the process of the commercialization, the hulless barley variety 'Kornelija' has been compared also with other types of cereals to explore the possibility to replace them as raw materials in production of different food products to increase the nutritional value demanded by consumers. For example, the dietary properties of oats are well known from ancient times, but the potential of barley in the prevention of cardiovascular diseases, positive impact on metabolic processes and low glycaemic index are mentioned in scientific publications just in previous decades (Jenkins et al., 2002; Wood et al., 2004; Mitsou et al., 2010; Havrlentova et al., 2011). The biochemical composition of 'Kornelija' was compared with the most popular widely grown types of cereals in Europe - oats, wheat, rye and hulled barley (Table 7).

\section{Comparison of nutritional value of 'Kornelija' with oats, wheat, rye and hulled barley}

\begin{tabular}{|l|c|c|c|c|c|}
\hline \multicolumn{1}{|c|}{ Traits } & Kornelija & $\begin{array}{c}\text { Hulled } \\
\text { barley }\end{array}$ & Oats $^{\text {a }}$ & Wheat $^{\text {a }}$ & Rye $^{\text {a }}$ \\
\hline Protein, \% in DM & $13.0-20.8$ & $8-17$ & $9-16$ & $8-15$ & $6-15$ \\
\hline$\beta$-glucans, \% in DM & $4.2-6.2$ & $3-9$ & $2-8$ & $0.2-0.9$ & 2 \\
\hline Total dietary fibre, \% in DM & $17.4-19.5$ & $11-34$ & $20-38$ & 13 & 17 \\
\hline Total fat, \% in DM & $2.0-2.3$ & $2-3$ & $4-7$ & $3-4$ & $1-2$ \\
\hline Vitamin E, mg $100 \mathrm{~g}^{-1}$ & $0.6-0.8$ & 0.6 & 0.4 & 0.1 & 0.9 \\
\hline Sum of EAA, g· kg ${ }^{-1}$ & $42.9-51.4$ & $34-44$ & 41 & 34 & $21-30$ \\
\hline EAA/Protein & $25-33$ & - & 39 & 37 & $15-25$ \\
\hline
\end{tabular}

Arendt \& Zannini, 2013.

Source: data of field trials 2015-2019. 
The comparison indicates that, in general, 'Kornelija' in protein content is higher than oats and much higher than wheat and rye. The total dietary fibre content in 'Kornelija' is comparable with it in oats and rye but the $\beta$-glucans content in 'Kornelija' $(4.2-6.2 \%)$ is twice as much as it in rye $(2 \%)$. Morrison has reported that total dietary fibre of barley consists of $\beta$-glucans, cellulose, fructan and glucomannan (Morrison, 1993). In turn, Vink and Delcour have reported that total dietary fibre of rye grains contains $\beta$-glucans, cellulose, lignin and arabinoxylan (Vink \& Delcour, 1996). Barley $\beta$-glucans composition differs also from $\beta$-glucans composition of oats and it is characterised with smaller molecular mass and different proportion of (1-3) $\beta$-glucan and (1-4) $\beta$-glucan, therefore with different impact on metabolic processes of humans (Arendt \& Zannini, 2013).

\section{Justification-cost-effectiveness of cultivation}

Another important challenge in the process of the commercialisation is to prove that the grains of 'Kornelija' are not only nutritionally valuable but can also be grown economically viable, as otherwise the new variety would not gain the interest of farmers and would most probable not enter the market.

Based on the methodology, the data and the assumptions described above, full variable costs of the cultivation of 'Kornelija' have been calculated. The calculations of full variable costs for different cultivation technologies are presented in Table 8 and Table 9.

Table 8

\section{Cost assessment of cultivation technologies without application of fungicides and retardants, 2019}

\begin{tabular}{|c|c|c|c|c|c|c|c|c|c|}
\hline \multirow[b]{2}{*}{ Indicators } & \multicolumn{9}{|c|}{ Cultivation technologies without application of fungicides and retardants ${ }^{\mathrm{a}}$} \\
\hline & $3 \mathrm{t} / 350$ & $3 t / 400$ & $3 \mathrm{t} / 450$ & $4 \mathrm{t} / 350$ & $4 \mathrm{t} / 400$ & $4 \mathrm{t} / 450$ & $5 \mathrm{t} / 350$ & $5 \mathrm{t} / 400$ & $5 \mathrm{t} / 450$ \\
\hline \multicolumn{10}{|l|}{ General parameters: } \\
\hline Expected yield, $\mathrm{t} \cdot \mathrm{ha}^{-1}$ & 3.0 & 3.0 & 3.0 & 4.0 & 4.0 & 4.0 & 5.0 & 5.0 & 5.0 \\
\hline Sowing rate, germinable seeds $\cdot \mathrm{m}^{-2}$ & 350 & 400 & 450 & 350 & 400 & 450 & 350 & 400 & 450 \\
\hline \multicolumn{10}{|l|}{ Yield: } \\
\hline Grain yield $^{\mathrm{b}}, \mathrm{t} \cdot \mathrm{ha}^{-1}$ & 4.03 & 4.25 & 4.27 & 4.29 & 4.25 & 4.35 & 4.43 & 4.33 & 4.48 \\
\hline Protein content, $\%$ in DM & 16.4 & 16.1 & 16.3 & 16.5 & 16.2 & 16.6 & 17.0 & 17.4 & 17.4 \\
\hline Protein yield, $\mathrm{kg} \cdot \mathrm{ha}^{-1}$ & 568 & 588 & 599 & 609 & 592 & 621 & 648 & 648 & 670 \\
\hline$\beta$-glucans content, $\%$ in DM & 4.9 & 4.9 & 4.9 & 4.8 & 4.7 & 4.8 & 4.9 & 4.8 & 4.8 \\
\hline$\beta$-glucans yield, $\mathrm{kg} \cdot \mathrm{ha}^{-1}$ & 170 & 179 & 180 & 177 & 172 & 180 & 187 & 179 & 185 \\
\hline \multicolumn{10}{|l|}{ Costs: } \\
\hline Seed, EUR $\cdot$ ha $^{-1}$ & 60 & 68 & 77 & 60 & 68 & 77 & 60 & 68 & 77 \\
\hline Fertilizer, EUR $\cdot$ ha $^{-1}$ & 62 & 62 & 62 & 88 & 88 & 88 & 113 & 113 & 113 \\
\hline Pesticides, EUR $\cdot \mathrm{ha}^{-1}$ & 7 & 7 & 7 & 7 & 7 & 7 & 7 & 7 & 7 \\
\hline Machinery operations, EUR $\cdot \mathrm{ha}^{-1}$ & 212 & 212 & 212 & 212 & 212 & 212 & 229 & 229 & 229 \\
\hline Grain cleaning, EUR $\cdot \mathrm{ha}^{-1}$ & 13 & 14 & 14 & 14 & 14 & 14 & 15 & 14 & 15 \\
\hline Grain drying, EUR $\cdot$ ha $^{-1}$ & 33 & 35 & 35 & 35 & 35 & 36 & 36 & 35 & 37 \\
\hline Transportation costs, EUR $\cdot \mathrm{ha}^{-1}$ & 12 & 13 & 13 & 13 & 13 & 13 & 13 & 13 & 13 \\
\hline Total variable costs, EUR $\cdot \mathbf{h a}^{-1}$ & 399 & 410 & 419 & 428 & 436 & 446 & 473 & 480 & 490 \\
\hline including EUR per tonne of grain & 99 & 97 & 98 & 100 & 103 & 102 & 107 & 111 & 109 \\
\hline $\begin{array}{l}\text { including EUR per tonne of } \\
\text { protein }\end{array}$ & 701 & 697 & 700 & 703 & 736 & 718 & 730 & 740 & 731 \\
\hline $\begin{array}{l}\text { including EUR per tonne of } \beta \text { - } \\
\text { glucans }\end{array}$ & 2347 & 2291 & 2329 & 2416 & 2537 & 2482 & 2531 & 2683 & 2651 \\
\hline
\end{tabular}

${ }^{a}$ figures before slash represent planned yield $\left(\mathrm{t} \cdot \mathrm{ha}{ }^{-1}\right)$, after the slash - sowing rate $\left(\mathrm{seed} \cdot \mathrm{m}^{-2}\right)$.

${ }^{\mathrm{b}}$ moisture 14\% (DM 86\%).

Source: data of field trial in 2019, the authors' calculations

The results of the calculations (Table 8) indicate that among the cultivation technologies without the application of fungicides and retardants the technology with the expected yield of $3 \mathrm{t} \cdot \mathrm{ha}^{-1}$ and sowing rate of $400 \mathrm{seeds} \cdot \mathrm{m}^{-2}$ (technology
$3 t$ / 400) had the lowest variable costs per tonne of grain, also per tonne of protein and tonne of $\beta$-glucans. 
Cost assessment of cultivation technologies with application of fungicides and retardants, 2019

\begin{tabular}{|c|c|c|c|c|c|c|}
\hline \multirow[b]{2}{*}{ Indicators } & \multicolumn{6}{|c|}{ Cultivation technologies with application of fungicides and retardants ${ }^{a}$} \\
\hline & $\begin{array}{c}4 \mathrm{t} / 350 \\
+\mathrm{FR}\end{array}$ & $\begin{array}{c}4 \mathrm{t} / 400 \\
+\mathrm{FR}\end{array}$ & $\begin{array}{c}4 \mathrm{t} / 450 \\
+\mathrm{FR}\end{array}$ & $\begin{array}{c}5 \mathrm{t} / 350 \\
+\mathrm{FR}\end{array}$ & $\begin{array}{c}5 \mathrm{t} / 400 \\
+\mathrm{FR}\end{array}$ & $\begin{array}{c}5 \mathrm{t} / 450 \\
+\mathrm{FR}\end{array}$ \\
\hline \multicolumn{7}{|l|}{ General parameters: } \\
\hline Expected yield, $\mathrm{t} \cdot \mathrm{ha}^{-1}$ & 4.0 & 4.0 & 4.0 & 5.0 & 5.0 & 5.0 \\
\hline Sowing rate, germinable seeds $\cdot \mathrm{m}^{-2}$ & 350 & 400 & 450 & 350 & 400 & 450 \\
\hline \multicolumn{7}{|l|}{ Yield: } \\
\hline Grain yield ${ }^{b}, \mathrm{t} \cdot \mathrm{ha}^{-1}$ & 5.16 & 5.13 & 5.20 & 5.43 & 5.40 & 5.61 \\
\hline Protein content, $\%$ in DM & 17.5 & 17.0 & 16.8 & 16.5 & 16.3 & 16.1 \\
\hline Protein yield, $\mathrm{kg} \cdot \mathrm{ha}^{-1}$ & 777 & 750 & 751 & 771 & 757 & 777 \\
\hline$\beta$-glucans content, $\%$ in DM & 4.8 & 4.9 & 4.7 & 4.8 & 4.9 & 4.7 \\
\hline$\beta$-glucans yield, $\mathrm{kg} \cdot \mathrm{ha}^{-1}$ & 213 & 216 & 210 & 224 & 228 & 227 \\
\hline \multicolumn{7}{|l|}{ Costs: } \\
\hline Seed, EUR $\cdot$ ha $^{-1}$ & 60 & 68 & 77 & 60 & 68 & 77 \\
\hline Fertilizer, EUR $\cdot$ ha $^{-1}$ & 88 & 88 & 88 & 113 & 113 & 113 \\
\hline Pesticides, EUR $\cdot$ ha $^{-1}$ & 41 & 41 & 41 & 41 & 41 & 41 \\
\hline Machinery operations, EUR $\cdot \mathrm{ha}^{-1}$ & 251 & 251 & 251 & 269 & 269 & 269 \\
\hline Grain cleaning, EUR $\cdot \mathrm{ha}^{-1}$ & 17 & 17 & 17 & 18 & 18 & 18 \\
\hline Grain drying, EUR $\cdot$ ha $^{-1}$ & 42 & 42 & 43 & 44 & 44 & 46 \\
\hline Transportation costs, EUR $\cdot \mathrm{ha}^{-1}$ & 15 & 15 & 16 & 16 & 16 & 17 \\
\hline Total variable costs, EUR $\cdot \mathbf{h a}^{-1}$ & 514 & 522 & 532 & 561 & 569 & 581 \\
\hline including EUR per tonne of grain & 100 & 102 & 102 & 103 & 105 & 103 \\
\hline including EUR per tonne of protein & 662 & 696 & 708 & 728 & 752 & 747 \\
\hline $\begin{array}{l}\text { including EUR per tonne of } \beta \text { - } \\
\text { glucans }\end{array}$ & 2414 & 2416 & 2531 & 2502 & 2500 & 2560 \\
\hline
\end{tabular}

${ }^{a}$ figures before slash represent expected yield $\left(\mathrm{t} \cdot \mathrm{ha}^{-1}\right)$, after the slash - sowing rate $\left(\mathrm{seed} \cdot \mathrm{m}^{-2}\right)$,

FR - using of fungicides and retardants

${ }^{\mathrm{b}}$ moisture 14\% (DM 86\%)

Source: data of field trial in 2019, the authors' calculations

Among the cultivation technologies with the application of all plant protection products (Table 9) the technology with expected yield of $4 \mathrm{t} \cdot \mathrm{ha}^{-1}$ and sowing rate of 350 germinable seed per $\mathrm{m}^{2}$ (technology $4 \mathrm{t} / 350$ ) had the lowest variable costs per tonne of grain, also per tonne of protein and tonne of $\beta$ glucans.
As protein content and protein yield varies among different cultivation technologies (both with and without application of plant protection products), to evaluate the relationship between protein content and protein yield these parameters are depicted graphically in Figure 3.

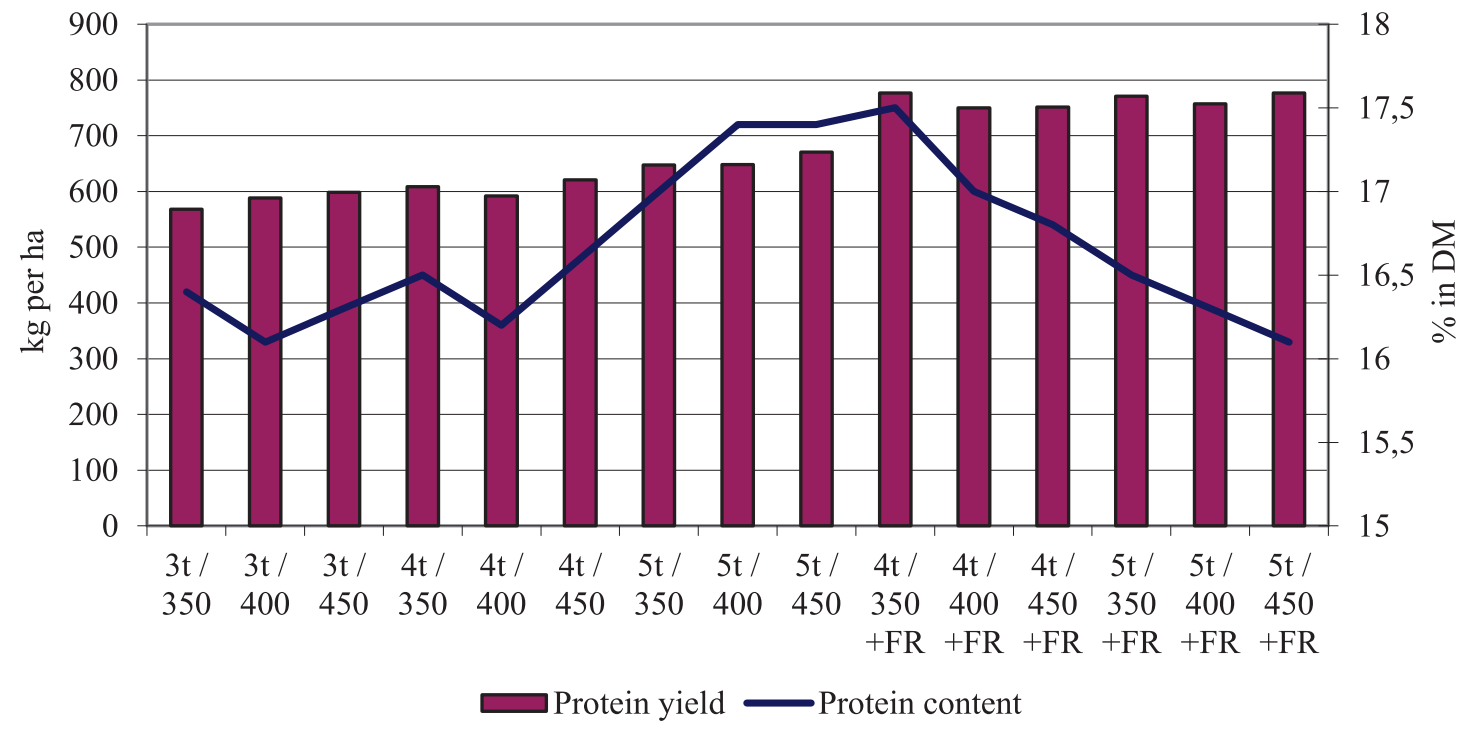


Figure 3. Protein yield and protein content of hulless barley variety 'Kornelija' under different cultivation technologies, 2019.

According to the results of graphical analysis, technology with the application of plant protection products, expected yield of $4 \mathrm{t} \cdot \mathrm{ha}^{-1}$ and sowing rate of 350 germinable seed per $\mathrm{m}^{2}$ (technology 4t / 350+FR) had both the highest protein content and highest protein yield (Figure 3). Thus, this technology can be regarded as the most appropriate option to grow 'Kornelija' as high protein content raw material for food processing, if only protein content and yield is considered. However, significant factor is also the costs of cultivation. Moreover, both variable costs per tonne of protein and variable costs per tonne of grain should be regarded. Based on the principle that money should be paid for the value, manufacturers should be interested to pay not just for the amount of supplied grain but the content (in the case of healthy and niche products, primary for protein and $\beta$ -glucans). That would facilitate farmers to become more motivated to grow varieties that provide not just high yields but are also nutritionally valuable.

In order to determine the most cost-effective cultivation technology of 'Kornelija', the results of variable cost calculations for different cultivation technologies are depicted in two dimensions - variable costs per tonne of protein and variable costs per tonne of $\beta$-glucans (Figure 4). The underlying principle is the following: technologies that are closer to the intersection of axes are regarded as more cost-efficient.

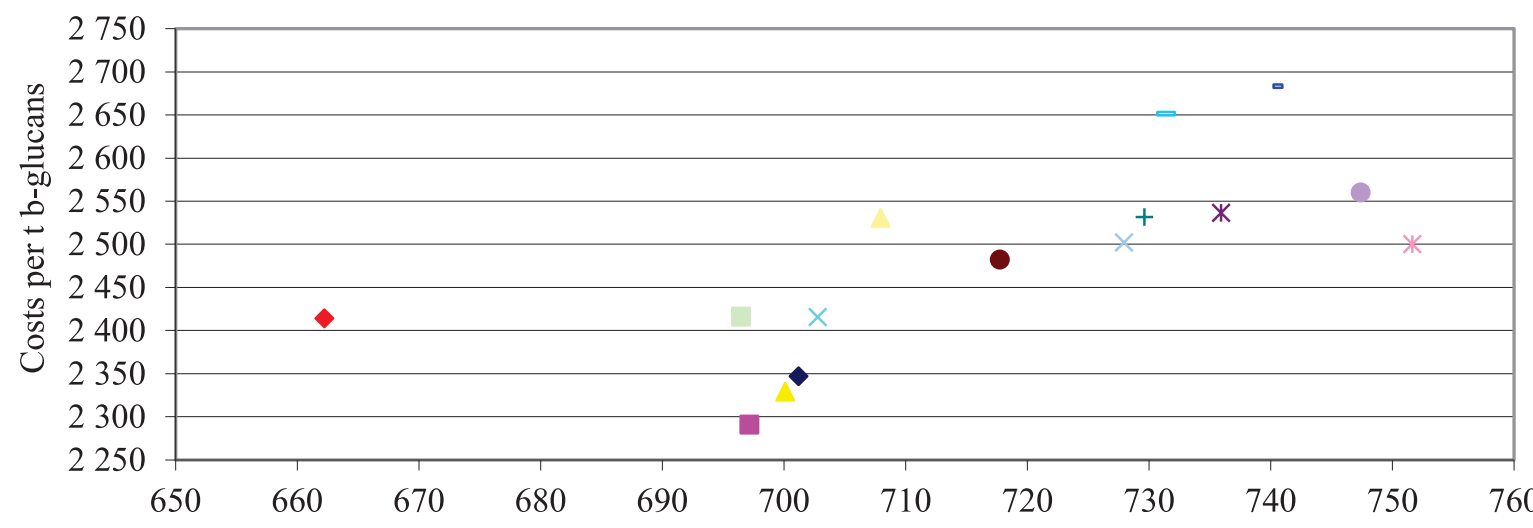

Costs per tonne of protein

$\begin{array}{lllll}\bullet 3 \mathrm{t} / 350 & \square 3 \mathrm{t} / 400 & \Delta 3 \mathrm{t} / 450 & \times 4 \mathrm{t} / 350 & * 4 \mathrm{t} / 400 \\ -4 \mathrm{t} / 450 & +5 \mathrm{t} / 350 & -5 \mathrm{t} / 400 & -5 \mathrm{t} / 450 & \diamond 4 \mathrm{t} / 350+\mathrm{FR} \\ 4 \mathrm{t} / 400+\mathrm{FR} & 4 \mathrm{t} / 450+\mathrm{FR} & \times 5 \mathrm{t} / 350+\mathrm{FR} & * 5 \mathrm{t} / 400+\mathrm{FR} & \bullet 5 \mathrm{t} / 450+\mathrm{FR}\end{array}$

Figure 4. Total variable costs in EUR per tonne of protein and per tonne of $\beta$-glucans under different cultivation technologies.

The graphical evaluation reveals that two technologies ( $4 \mathrm{t}$ / $350+\mathrm{FR}$ and $3 \mathrm{t} / 400)$ can be regarded as the most costefficient (Figure4).

Both of these best performing cultivation technologies ( $4 \mathrm{t}$ $/ 350+\mathrm{FR}$ and $3 \mathrm{t} / 400$ ) were further evaluated in comparison with the yield of protein and $\beta$-glucans of such typical cereal crops as winter wheat, spring wheat, oats and hulled barely. Protein yield and $\beta$-glucans yield were also depicted in two dimensions (see Figure 5), allowing to identify crops that provide both high protein yield and $\beta$-glucans. The crops that are farther from the intersection of axes have better potential to provide both protein and $\beta$-glucans. 


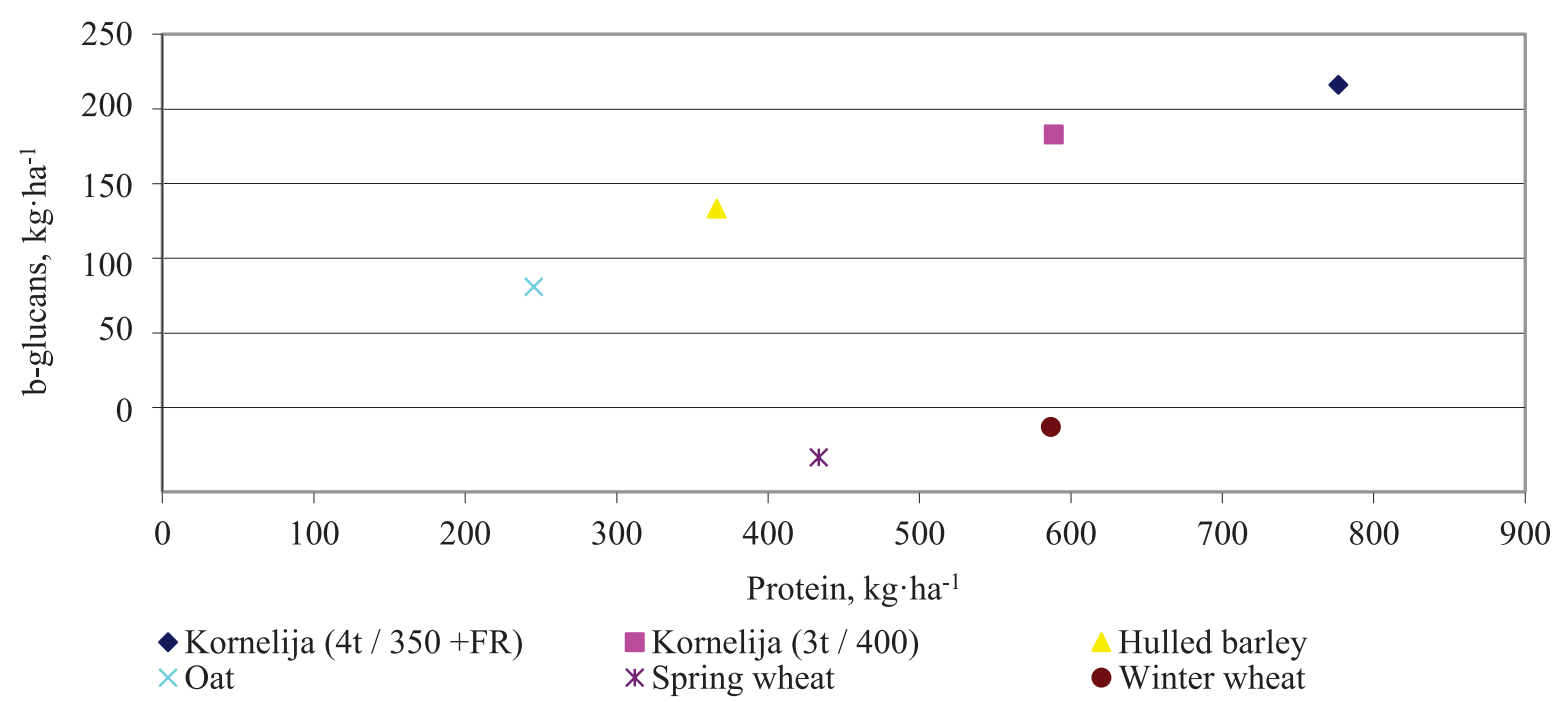

Source: European Agricultural Fund (EAFRD) project (supported by Ministry of Agriculture) "Demonstration of the integrated cultivation of prospective Latvian wheat, oat and barley varieties in different regions of Latvia" (Stende, 2019)

Figure 5. Yield of protein and $\beta$-glucans for cultivation technologies of 'Kornelija' $(4 \mathrm{t} / 350+\mathrm{FR}$ and $3 \mathrm{t} / 400)$ and other cereals.

The graphical evaluation of the yield of protein and $\beta$ glucans reveals that 'Kornelija' outperforms other crops - not only hulled barley, oats and spring wheat but also winter wheat (Figure 5), and the best performance is achieved under the technology $4 \mathrm{t} / 350+\mathrm{FR}$. These results allow to conclude that 'Kornelija' (especially cultivated under the technology $4 \mathrm{t}$
/ $350+\mathrm{FR}$ is the most appropriate crop to simultaneously provide high volume of protein and $\beta$-glucans.

Also, break-even prices have been calculated for both promising cultivation technologies of 'Kornelija' (4t / 350 $+\mathrm{FR}$ and $3 \mathrm{t} / 350)$, and the results are presented in Table 10 .

Break-even prices, EUR per tonne, 2019

Table 10

\begin{tabular}{|l|c|c|c|c|}
\hline \multirow{2}{*}{ Cultivation technologies } & \multicolumn{3}{|c|}{ Reference crops (price for the crop ${ }^{\text {a }}$ EUR $\mathrm{t}^{-1}$ ) } \\
\cline { 2 - 5 } & $\begin{array}{c}\text { Spring wheat } \\
(162)\end{array}$ & $\begin{array}{c}\text { Winter wheat } \\
(162)\end{array}$ & $\begin{array}{c}\text { Oats } \\
(157)\end{array}$ & $\begin{array}{c}\text { Hulled barley } \\
(134)\end{array}$ \\
\hline 'Kornelija' technology 4t / 350 +FR & 127 & 156 & 111 & 99 \\
\hline 'Kornelija' technology 3t / 400 & 130 & 165 & 110 & 95 \\
\hline
\end{tabular}

${ }^{a}$ price in 2019 (LRAT, 2020)

As wheat (especially winter wheat) is the most popular crop to grow among farmers in Latvia, break-even prices based on spring wheat and winter wheat as reference crops are analysed. The calculated break-even prices indicate that 'Kornelija' is quite competitive as a raw material. Under the technology $4 \mathrm{t} / 350+\mathrm{FR}$, break-even price $\left(\mathrm{P}_{\mathrm{b}}\right)$ is $127 \mathrm{EUR} \cdot \mathrm{t}^{-1}$ (if spring wheat is a reference crop) and $156 \mathrm{EUR} \cdot \mathrm{t}^{-1}$ (if winter wheat is a reference crop). Thus, $\mathrm{P}_{\mathrm{b}}$ is $22 \%$ and $2 \%$ lower than the price of wheat respectively. Under the technology $3 \mathrm{t} / 400$, $P_{b}$ is $130 \mathrm{EUR} \cdot \mathrm{t}^{-1}$ (if spring wheat is a reference crop) and 165 EUR $\cdot t^{-1}$ (if winter wheat is a reference crop). Thus, $\mathrm{P}_{\mathrm{b}}$ is $20 \%$ lower and $4 \%$ higher than the price of wheat respectively. It should be noted that if the reference crop is winter wheat, $\mathrm{P}_{\mathrm{b}}$ is higher than the price of hulled barley (134 EUR $\left.\cdot t^{-1}\right): 17 \%$ higher for the technology $4 \mathrm{t} / 350+\mathrm{FR}$ and $23 \%$ higher for the technology $3 \mathrm{t} / 400$.

The results of the analysis and evaluation indicate that the technology 4t / $350+\mathrm{FR}$, including moderately high use of fertilisers, reduced sowing rate and the use of fungicides and retardants, was the most appropriate cultivation technology that provides the best opportunities for the commercialization of the new hulless barley variety 'Kornelija'. This technology had the highest cost-efficiency and competitiveness with wheat (both winter and spring wheat), as well it provides the highest protein content, protein yield and $\beta$-glucans yield. The technology 3t / 400 was less appropriate option; however, it has some prospects if the use of fertilizers is restricted and the use fungicides and retardants are not possible.

By paying for the grains of 'Kornelija' the price that is equal or higher than the break-even price (reference crop winter wheat), food processors would both motivate farmers to grow 'Kornelija' and at the same time obtain a raw material with highly valuable nutritional properties for production of functional products at a reasonable price (e.g., grains with much higher protein content, significantly higher $\beta$-glucans content than winter wheat for a price that is close to the price of winter wheat).

\section{Conclusions}

High protein content and the sum of essential amino acids, as well as high dietary fibre content are the main 
reasons to consider the grains of 'Kornelija' as a promising raw material for healthy food production. The hulless barley variety 'Kornelija' may not only replace the currently used raw materials in functional food production, but also become a source of inspiration for the development of new food products and the implementation thereof in production.

Results of the long-term field trials showed that 'Kornelija' ripens earlier than standard barley varieties, provides coarse grains, heightened test weight and good resistance to lodging and diseases but its yield potential is intermediate, which does not create the initial demand from farmers, therefore the pull from processors is necessary, and the commercialisation process was implemented to facilitate it.

According to the field trials of 2019, it has been concluded that the cultivation technology with moderately high use of fertilisers (expected yield $4.0 \mathrm{t} \cdot \mathrm{ha}^{-1}$ ), reduced sowing rate (350 germinable seed per $\mathrm{m}^{2}$ ) and the use of fungicides and retardants provides the best opportunities for the commercialization of the new hulless barley variety 'Kornelija' due to the highest cost-efficiency and the highest protein content, protein yield and $\beta$-glucans yield.

It has also been found that by offering for the grains of 'Kornelija' the price that is equal or higher than winter wheat referenced break-even price, farmers motivation to grow the variety would increase, while processors would obtain grains with much higher protein content, and significantly higher $\beta$ glucans content than winter wheat to produce functional foods for a price that is close to the price of winter wheat.

Overall, the introduction of new elements of biochemical composition of grain in the payment system of raw material purchase by food processors should promote the entry of nutritionally valuable grain varieties in the market.

\section{References}

Aarikka-Stenroos, L., Sandberg, B. (2012). From newproduct development to commercialization through networks. Journal of Business Research, 65(2), 198206. DOI: 10.1016/j.jbusres.2011.05.023.

Aarikka-Stenroos, L., Sandberg, B., \& Lehtimäki, T. (2014). Networks for the commercialization of innovations: A review of how divergent network actors contribute. Industrial Marketing Management. 43(3), 365-381. DOI: 10.1016/j.indmarman.2013.12.005.

Clément, T., Joya, R., Bresson, C., \& Clément, C. (2018). Market developments and policy evaluation aspects of the plant protein sector in the EU. Brussels: Agrosynergie EEIG for the European Commission.

Akhundjanov, S. B., Gallardo, R. K., \& McCluskey, J. J., Rickard, B. J. (2019). Commercialization of a demandenhancing innovation: The release of a new apple variety by a public university. Economic Modelling. 86, 88-100. DOI

10.1016/j.econmod.2019.06.004.

Arendt, E.K. \& Zannini, E. (2013). Cereal grains for the food and beverage industries. Cambridge, UK: Woodhead Publishing Series.

Auzins A., Krievina A., \& Leimane I. (2019). Environmental Benefits from Shortening Soybean Meal Delivery Chain in Latvia. Ecology, Economics, Education and Legislation: International Multidisciplinary Scientific GeoConference-SGEMProceedings, 19(5.3), 275-281. DOI: $10.5593 /$ sgem 2019/5.3/S21.035.
Baik, B.K. \& Ullrich, S.E. (2008). Barley for food: Characteristics, improvement, and renewed interest. Journal of Cereal Science, 48(2), 233-242.

DOI: $10.1016 /$ j.jcs.2008.02.002.

Biel, W. \& Jacyno, E. (2013). Chemical composition and nutritive value of spring hulled barley varieties. Bulgarian Journal of Agricultural Sciences, 19(4), 721-727. DOI: 10909510/721

Bleidere, M.\& Grunte, I. (2015). Kailgraudu vasaras miežu škirnes 'Kornelija' saimnieciskais un graudu biokīmiskais rasturojums (Economic and biochemical characteristics of hulless barley variety 'Kornelija'). Zinātniski praktiskā konference

“Lìdzsvarota Lauksaimniecība” raksti. 192-195. 1pp. (in Latvian)

Bleidere, M., Zute, S., Brunava, L., Bobere, N., \& Jākobsone, I. (2013b). Yield and grain quality of hulless spring barley in field trials under different nitrogen management conditions. Proceedings of the Latvian Academy of Sciences. Section B: Natural, Exact and Applied Sciences, 67(3), 229 - 235.

DOI: $10.2478 /$ prolas-2013-0040

Bleidere, M., Zute, S., \& Jakobsone, I. (2013a). Characterisation of physical and biochemical traits of hulless spring barley grain in Latvian breeding program. Proceedings of the Latvian Academy of Sciences. Section B, 67(4), 399-404. DOI: 10.2478/prolas-2013-0065

European Commission (2018). Report from the Commission to the Council and the European Parliament on the development of plant proteins in the European Union. Brussels: European Commission.

European Commission (2021). Plant-based foods in Europe: How big is the market? Smart Protein Plant-based Food Sector Report by Smart Protein Project, European Union's Horizon 2020 research and innovation programme (No 862957). Retrieved October 20, 2021, from

https://smartproteinproject.eu/plant-based-foodsector-report/.

Havrlentova, M., Petrulakova, Z., Burgarova, A., Gago, F., Hlinkova, A., \& Šturdík, E. (2011). $\beta$-glucans and their significance for the preparation of functional foods-a review. Czech Journal of Food Sciences, 29(1), 1-14. DOI: $10.17221 / 162 / 2009-C J F S$

Henchion, M., Hayes, M., Mullen, A., Fenelon, M., \& Tiwari, B. (2017). Future protein supply and demand: strategies and factors influencing a sustainable equilibrium. Foods, 6(7), Article No 53. D O I : $10.3390 /$ foods 6070053

Hoehnel, A., Axel, C., Bez, J., Arendt, E. K., \& Zannini, E. (2019). Comparative analysis of plant-based highprotein ingredients and their impact on quality of highprotein bread. Journal of Cereal Science, 89, Article No 102816. DOI: 10.1016/j.jcs.2019.102816.

Janssen, M., Busch, C., Rödiger, M., \& Hamm, U. (2016), Motives of consumers following a vegan diet and their attitudes towards animal agriculture. Appetite, 105, 643-651. DOI: 10.1016/j.appet.2016.06.03.

Jenkins A.L., Jenkins D.J.A., Zdravkovic U., Wursch P., \& Vuksan V. (2002). Depression of the glycaemic index by high levels of beta-glucan fiber in two functional foods tested in type 2 diabetes. European Journal of Clinical Nutrition, 56(7), 622-628. 
DOI: $10.1038 /$ sj.ejen. 1601367

Lancashire P.D., Bleiholder H., Van Den Boom T., Langeluuddeke P., Strauss R., Webern E., Witzenberger A. (1991). A uniform decimal code for growth stages of crops and weed. Annals of Applied Biology, 119(3), 561-601. DOI: 10.1111/j.1744-7348.1991.tb04895.x

Latvian Rural Advisory and Training Centre (LRAT) (2020, June). Lauksaimniecības bruto segumu aprēķini par 2019. gadu (Agricultural gross margin calculations for 2019). Retrieved April 22, 2020, from

http://new.1lkc.lv/lv/nozares/augkopiba-ekonomikalopkopiba/sagatavoti-bruto-segumi-par-2019-gadu. (in Latvian)

Leguizamón, A. (2014). Modifying Argentina: GM soy and socio-environmental change. Geoforum, 53, 149-160. DOI: 10.1016/j.geoforum.2013.04.001.

Lin, D., Lu, W., Kelly, A. L., Zhang, L., Zheng, B., \& Miao, S. (2017). Interactions of vegetable proteins with other polymers: Structure-function relationships and applications in the food industry. Trends infood science \& technology, 68, 130-144.

DOI: $10.1016 /$ j.tifs. 2017.08 .006

Macdougall, W.A.J. \& Selvendran, R.R. (2001). Chemistry, architecture and composition of dietary fiber from plant cell walls. In Cho, S.S. \& Dremer, M.L (Eds.), Handbook of Dietary Fiber (pp.281-319). New York: Marcell Dekker.

Martinez-Ribaya, B. \& Areal, F. J. (2020). Is there an opportunity for product differentiation between GM and non-GM soya-based products in Argentina? Food Control, 109, Article 106895. DOI:

10.1016/j.foodcont.2019.106895.Menna, A. \& Walsh, P. R. (2019). Assessing environments of commercialization of innovation for SMEs in the global wine industry: A market dynamics approach. Wine Economics and Policy, 8(2), 191-202. DOI: 10.1016/j.wep.2019.10.001.

Mitsou, E.K., Panopoulou, N., Turunen, K., Spiliotis, V., \& Kyriacou, A. (2010). Prebiotic potential of barley derived $\beta$-glucan at low intake levels: A randomised, double-blinded, placebo-controlled clinical study. Food Research International, 43(4), 1086-1092. DOI: 10.1016/j.foodres.2010.01.020.

Morrison, W.R. (1993). Barley lipids. In Macgregor, A.W. \& Bhatty, R.S. (Eds.), Barley: Chemistry and Technology (pp.73-130). St Paul, MN: AACC International, Inc.,.

Mellentin, J. (2019). Key Trends in Food, Nutrition Health 2020. London: New Nutrition Business.

Öberg, C. \& Shih, T. T. Y. (2014). Divergent and convergent logic of firms: Barriers and enablers for development and commercialization of innovations. Industrial Marketing Management, 43(3), 419-428. DOI: 10.1016/j.indmarman.2013.12.010.

Paynter, B.H. \& Harasymow, S.E. (2010). Variation in grain $\beta$-glucan due to site, cultivar and nitrogen fertiliser in Western Australia. Crop Pasture Science, 61(12), 1017 1026. DOI: $10.1071 / \mathrm{CP} 10146$

Shaveta, Kaur H., \& Kaur S. (2019). Hulless barley: A new era of research for food purposes. Journal for Cereal Research, 11(2), 114-124. DOI:10.25174/22494065/2019/83719

Sterna, V., Zute, S., \& Jakobsone, I. (2015). Grain composition and functional ingredients of barley varieties created in Latvia. Proceedings of the Latvian Academy of Sciences, Section B, 69(4), 158-162. DOI:10.1515/prolas-2015-0023

Sterna, V., Zute S., Jansone I., \& Kantane I. (2017). Chemical composition of covered and naked spring barley varieties and their potential for food production. Polish Journal of Food and Nutrition Sciences, 67(2), 151-155. DOI:10.1515/pjfns-2016-0019

Sturite, I., Kronberga, A., Strazdina, V., Kokare, A., Aassveen, M., Kari A., \& Olsen, B. (2019). Adaptability of hull-less barley varieties to different cropping systems and climatic conditions. Acta Agriculture Scandinavica, Section B - Soil \& Plant Science, 69(1), 1-11. DOI: 10.1080/09064710.2018.1481995

Peltonen-Sainio, P., Jauhiainen, L., \& Nissilä, E. (2012). Improving cereal protein yields for high latitude conditions. European journal of agronomy, 39, 1-8. DOI: 10.1016/j.eja.2012.01.002.

Rajala, A., Hakala, K., Mäkelä, P., \& Peltonen-Sainio, P. (2011). Drought effect on grain number and grain weight at spike and spikelet level in six-row spring barley. Journal of Agronomy and Crop Science, 197(2), 103-112. DOI:10.1111/j.1439-037X.2010.00449.x

Talke, K. \& Hultink, E. J. (2010). Managing diffusion barriers when launching new products. Journal of Product Innovation Management, 27(4), 537-553. DOI: 10.1111/j.1540-5885.2010.00734.x

Tamm, U, Jansone, I, Zute, S, \& Jakobsone, I. (2015). Genetic and environmental variation of barley characteristics and the potential of local origin genotypes for food production. Proceedings of the Latvian Academy of Sciences. Section B. Natural, Exact, and Applied Sciences, 69, 163-169. DOI: $10.1515 /$ prolas-2015-0024

Vink, C.J.A. \& Delcour, J., A. (1996). Rye (Secale cereal L.) arabinoxylans: A critical review. Journal Cereal Sciences, 24(1), 1-14. DOI: 10.1006/jcrs.1996.0032

World Health Organization \& United Nations University. (2007). Protein and amino acid requirements in human nutrition. Geneva: World Health Organization. (Vol. 935, Issue 1)

Wood, P.J. (2004). Relationships between solution properties of cereal b-glucans and physiological effects-a review. Trends in Food Science \& Technology, 15(6), 313-320. DOI: 10.1016/j.tifs.2003.03.001.

Winger, R., \& Wall, G. (2006). Food product innovation. Rome: Food and Agriculture Organization.

Yu, Z., Nan, F., Wang, L. Y., Jiang, H., Chen, W., \& Jiang, Y. (2019). Effects of high-protein diet on glycemic control, insulin resistance and blood pressure in type 2 diabetes: A systematic review and meta-analysis of randomized controlled trials. Clinical Nutrition, 39, 1724-1734. DOI: 10.1016/j.clnu.2019.08.008.

\section{Acknowledgement}

The research has been supported by the ERDF project No. KC-PI-2017/43. Thanks are extended to Lars Gradin, Stein Bergersen and Pawel Czembor for providing seed of hulless barley varieties. 